\title{
Toxicity and development of tolerance in cattle to timber milkvetch
}

\author{
W. MAJAK, L. STROESSER, T. LYSYK, AND J.W. HALL
}

Authors are Toxic Plant Biochemist and Range Manager, Agriculture and Agri-Food Canada (AAFC) Range Research Unit, 3015 Ord Road, Kamloops, B.C. V2B 8A9, Entomologist, AAFC Research Centre, Lethbridge, AB, TIJ 4BI and Biostatistician, Pacific Agri-Food Research Centre, Summerland, B.C. V0H 1Z0.

\begin{abstract}
Timber milkvetch (TMV, Astragalus miser Dougl. ex Hook var. serotinus) is widely distributed on rangelands in the southern interior of British Columbia, Canada. It synthesizes large quantities of miserotoxin, a glycoside that is toxic to cattle. Six grazing studies were conducted at Sixtyone Creek on the Cariboo Plateau during 1993 to 2000 to determine which class of livestock was most susceptible to TMV, to record clinical signs of poisoning under range conditions, and to determine the efficacy of protein supplements for the prevention of TMV poisoning. In vitro rates of TMV detoxification in rumen fluid were determined concurrently. Incidents of early, acute and chronic poisoning were documented using a total of 143 cows over the 6 year study. Older cows (more than 3-years old) and yearling heifers were less susceptible to TMV than lactating first-calf heifers, which showed acute signs of poisoning. A chronic syndrome was sometimes seen in second-calf heifers, especially during exertion. Heifers not previously exposed to TMV, such as those that were obtained from the prairie region of Alberta, were also more susceptible than cattle originating in B.C. with a known history of exposure to TMV. Each year, Hereford cows were divided into 2 groups, one of which received free-choice protein supplements in a molasses block, the other did not receive supplement and served as a control group during the 6-week grazing trial. The control group yielded 25 cases of TMV poisoning during the 6-year study, compared with 2 for the supplement group. However, the supplement increased rates of TMV detoxification $(>50 \%)$ in only 1 of the 5 years of testing. Native cattle yielded higher rates of TMV detoxification (> 25\%) in 2 of the 5 years than introduced cattle. The innate capacity to transfer rumen microbial activity between cattle in close proximity and the natural enrichment of rumen microbial populations could elevate rates of detoxification regardless of supplement or origin.
\end{abstract}

Key Words: poisonous plants, Astragalus miser var. serotinus, detoxification, protein supplements.

The Interior Douglas Fir (Pseudotsuga menziesii (Mirb.) Franco) zone is the most important forest zone for cattle grazing

\footnotetext{
The authors would like to thank Ruth McDiarmid and summer students Cindy Hunter, Monica Durigon, Jessica Herauf and Barbara Wheatley for conducting in vitro assays and lab analyses; Keith Ogilvie, Greg and Ross Syme for care and handling of livestock; and the B.C. Ministry of Forests, 100 Mile District for their support. The study was partially funded by the Beef Cattle Industry Development Fund (Projects \#4, \#82 and \#125).

Manuscript accepted 8 Aug. 01.
}

Resumen

“Timber milkvetch" (TMV, Astragalus miser Dougl. ex Hook var. serotinus) esta ampliamente distribuida en los pastizales del sur de Columbia Británica, Canadá. Esta especies sintetiza grandes cantidades de miserotoxina, un a glicóosido que es tóxico para el ganado. De 1993 a 2000 se realizaron 6 estudios de apacentamiento en el Arroyo Sixtyone en la Meseta Cariboo para determinar que clase de ganado fue mas susceptible a TMV, registrar los signos clínicos de envenenamiento bajo condiciones del pastizal y determinar la eficacia de suplementos proteicos para prevenir el envenenamiento por TMV. Las tasas de detoxificación in vitro de TMV en el fluido ruminal se determinaron concurrentemente. Incidentes de intoxicación inicial, aguda y crónica se documentaron usando un total de 143 vacas en los 6 años de estudio. Las vacas viejas (mas de 3 años de edad )y las vaquillas de un año fueron menos susceptibles al TMV que las vacas lactantes de primer parto, las cuales mostraron signos agudos de intoxicación. A veces se observó un síndrome crónico envacas de segundo parto, especialmente durante el parto. Las vaquillas no expuestas previamente al TMV, tales como las que fueron obtenidas de la región de praderas de Alberta, fueron también mas susceptibles que el ganado originario de Columbia Británica con una historia conocida de exposición al TMV. Cada año las vacas Herford se dividieron en 2 grupos, uno de los cuales recibió suplementos proteicos a libre acceso en bloques de melaza, el otro grupo no fue suplementado y sirvió como control durante el ensayo de apacentamiento de 6 semanas. El grupo control produjo 25 casos de intoxicación por TMV durante el periodo de estudio de 6 años, comparado con 2 casos del grupo suplementado. Sin embargo, el suplemento incrementó las tasas de desintoxicación de TMV (>50\%) en solo 1 de 5 años de prueba. El ganado nativo produjo tasas más altas de desintoxicación (>25\%) en 2 de los 5 años que las del ganado introducido. La capacidad innata para transferir la actividad ruminal microbiana entre el ganado en una proximidad cercana y el enriquecimiento natural de las poblaciones microbianas del rumen pueden elevar las tasas de desintoxicación, sin importar el suplemento o el origen.

in southern British Columbia (Wikeem et al. 1993). Timber milkvetch (TMV), also known as Columbia milkvetch (Astragalus miser Dougl. ex Hook. var. serotinus), is a legume that can be abundant in this zone, especially in lodgepole pine (Pinus contorta Dougl. ex Loudon) forests on the Cariboo Plateau. The crude protein content of TMV is relatively high (Majak et al. 1996) but TMV also synthesizes large quantities of 
miserotoxin, a glycoside of 3-nitropropanol $(\mathrm{NPOH})$ that causes acute and chronic poisoning in ruminants (Maricle et al. 1996). The glycoside is rapidly hydrolyzed by rumen bacteria to the aglycone, NPOH, which is then absorbed and oxidized to 3-nitropropionic acid (Majak and Pass 1989), a potent inhibitor of mitochondrial enzymes essential to respiration (Alston et al. 1977, Coles et al. 1979).

Rumen bacteria also have the capacity to degrade and detoxify NPOH, and the rate of degradation can be enhanced by increasing the amount of protein in the diet (Majak et al. 1998). The detoxification of NPOH by Denitrobacterium detoxificans, a recently identified rumen bacterium, involves the reduction of the nitro group to the much less toxic amino group (Anderson et al. 1993, 1997). One strain of this bacterium (MAJ1) originated from the rumen bacteria of cattle grazing our study area in the Cariboo (Anderson et al. 2000).

The objectives of this study were to determine which age class of cattle was most susceptible to TMV, to record clinical signs of poisoning under range conditions, and to confirm the efficacy of protein supplements for the prevention of TMV poisoning. The effect of prior exposure to TMV on susceptibility to TMV was also determined. An additional objective during the 6 year study was to evaluate the detoxification potential of rumen bacteria using in vitro assays.

\section{Materials and Methods}

Two, 40 ha forest pastures (designated $\mathrm{A}$ and B) at Sixtyone Creek, B.C. ( $51^{\circ} 14^{\prime}$ $\mathrm{N}$ lat., $121^{\circ} 34^{\prime} \mathrm{W}$. long.) used for this study were described earlier (Majak et al. 1996).Pinegrass (Calamagrostis rubescens Buckl.) was the principal native grass and the distribution of the 10 major forbs is described in Table 1. It should be noted that in the earlier study (Majak et al. 1996) the 2 major forbs at the forest site were incorrectly assigned to a grassland site and vice versa. A third pasture (designated $\mathrm{C}$ ) of equal area was added in 1993 by enclosing the area between pastures $A$ and $\mathrm{B}$ with permanent fences. This pasture had been clearcut logged in 1977. The average density of timber milkvetch (TMV, 12 plants $\mathrm{m}^{-2}$ ) in pastures A and B (Majak et al. 1996) was significantly higher $(\mathrm{P}<$ $0.05)$ than in pasture $C\left(6\right.$ plants $\left.\mathrm{m}^{-2}\right)$. The average TMV basal area per plant $(3.14$

Table 1. Frequency ${ }^{1}$ of 10 major forbs at Sixtyone Creek.

\section{Species}

Fragaria virginiana Duchesne

Achillea millefolium $\mathrm{L}$.

Taraxacum officinale Weber

Antennaria parvifolia Nutt.

Agoseris glauca var. dasycephla (T. \& G.) Jeps

Solidago sphathulata DC.

Galium boreale L.

Aster conspicuous Lindl.

Erigeron speciosus var. speciosus (Lindl.) DC. Melampyrum lineare Desr.

Total

${ }^{1}$ Estimated from 120, 1-m² plots (Majak et al. 1996).

$\left.\mathrm{cm}^{2}\right)$ did not differ among the pastures $(\mathrm{P}$ $=0.13$ ). Estimates of the miserotoxin content of TMV at the site vary from $2.5 \%$ to $3.7 \%$ on a dry weight basis (Majak et al. 1996, Majak and Wikeem 1986).

During 1993 and 1995-2000, cattle on test were divided into 2 groups, one of which received protein supplements in molasses blocks and the other served as a control. The treated cattle were exposed to the molasses blocks at Pass Lake on forest range near Kamloops, B.C. for at least 2 weeks before grazing commenced at Sixtyone Creek where blocks were given free choice for the duration of the 6 week study each year. The blocks contained $32 \%$ crude protein (Uniblok Canada, Rockyford, AB) including canola, corn gluten and feather meal $(20 \%)$, urea $(12 \%)$, minerals and salt. The control group received a block of cobalt iodized stock salt.

Rumen samples were obtained from the Hereford cows with the stomach pump sampling technique using a speculum to insert a plastic hose attached to a manual pump. Animals were cared for under the guidelines of the Canadian Council on Animal Care. The details of the anaerobic in vitro procedures and the spectrophotometric methods for determining rates of $\mathrm{NPOH}$ disappearance in rumen fluid were reported earlier (Majak 1992). Using a portable generator to maintain a waterbath at $39^{\circ} \mathrm{C}$, samples of rumen fluid were anaerobically incubated with NPOH (2 $\mathrm{mM}$ ) under field conditions, then subsamples were treated with the protein precipitant and cooled prior to transportation and spectrophotometric determination. Rates of NPOH disappearance in rumen fluid in vitro were determined at biweekly intervals for each animal on test.

\section{Grazing Trial}

Results of the 1993 grazing trial at Sixtyone Creek were reported earlier (Majak et al. 1996) except for the specific cases of timber milkvetch (TMV) poisoning, which are reported here (Table 2). Two groups of 10 Hereford cow-calf pairs were used in 1993, including 10 first-calf heifers ( 2 years old) and 10 cows, 4 to 10 years old (Table 2). Each group contained 5 heifers and 5 older cows. One group was given protein supplements in pasture $B$ and the control group grazed pasture A without any supplement.

In 1994, 2 types of protein blocks (Majak et al. 1998) were tested using 2 groups of 12 cow-calf pairs. The cows were 2 to 8 years old and there were no cases of TMV poisoning (unpublished data, Majak, W.). Grazing started each year in pasture C which was subdivided into 2 adjacent fields with electric fencing. After approximately 2 weeks of grazing in the clearcut compartment, 1 group moved east to $A$ and the other was moved west to B for the remainder of the 6 week grazing trial.

\section{5 and 1996 Grazing Trials}

In 1995 and 1996, 2 groups of 12 cowcalf pairs were tested with and without protein supplements. Since the 1993 grazing trial and previous studies during 19891992 (Majak et al. 1996, 1998) failed to produce signs of TMV poisoning among older cows, only younger cattle (2 to 3 years old) were used. A further modification in 1995 and 1996 involved the yearly purchase of 12 first-calf heifers from Alberta. These animals had not been previously exposed to TMV. The objective was to determine whether unexposed, "naive" animals of prairie origin were more susceptible to TMV poisoning than 
Table 2. Age, origin and number of cows in grazing studies during 1993-2000 and incidence and degree ${ }^{1}$ of TMV poisoning in control and supplement groups.

\begin{tabular}{|c|c|c|c|c|c|c|c|c|c|c|c|c|c|c|}
\hline \multirow{3}{*}{ Year } & \multirow{3}{*}{$\mathrm{n}$} & \multirow{3}{*}{$\frac{\text { Age }}{\text { (years) }}$} & \multicolumn{6}{|c|}{ Control group } & \multicolumn{6}{|c|}{ Supplement group } \\
\hline & & & \multicolumn{2}{|c|}{ Early } & \multicolumn{2}{|c|}{ Acute } & \multicolumn{2}{|c|}{ Chronic } & \multicolumn{2}{|c|}{ Early } & \multicolumn{2}{|c|}{ Acute } & \multicolumn{2}{|c|}{ Chronic } \\
\hline & & & $\mathrm{AB}^{2}$ & $\mathrm{BC}$ & $\mathrm{AB}$ & $\mathrm{BC}$ & $\mathrm{AB}$ & $\mathrm{BC}$ & $\mathrm{AB}$ & $\mathrm{BC}$ & $\mathrm{AB}$ & $\mathrm{BC}$ & $\mathrm{AB}$ & $\mathrm{BC}$ \\
\hline 1993 & 20 & $2-10$ & - & $2^{3}$ & - & $1^{3}$ & - & 1 & - & 0 & - & 0 & - & 0 \\
\hline 1995 & 24 & $2-3$ & 0 & 2 & 3 & 0 & 2 & 0 & 0 & 0 & 0 & 0 & 1 & 0 \\
\hline 1996 & 24 & $2-3$ & 0 & 0 & 1 & 0 & 1 & 1 & 0 & 0 & 0 & 0 & 0 & 0 \\
\hline 1998 & 30 & 1 & 0 & 0 & 0 & 0 & 0 & 0 & 0 & 0 & 0 & 0 & 0 & 0 \\
\hline 1999 & 24 & 2 & 4 & 1 & 0 & 1 & 0 & 0 & 0 & 0 & 1 & 0 & 0 & 0 \\
\hline 2000 & 21 & 3 & 0 & 0 & 0 & 0 & 2 & 3 & 0 & 0 & 0 & 0 & 0 & 0 \\
\hline Total & $143^{4}$ & & \multicolumn{2}{|c|}{9} & \multicolumn{2}{|c|}{6} & \multicolumn{2}{|c|}{10} & \multicolumn{2}{|c|}{0} & \multicolumn{2}{|c|}{1} & \multicolumn{2}{|c|}{1} \\
\hline
\end{tabular}

Clinical signs designated as early, acute, or chronic.

${ }^{2}$ In 1995 to 2000, origin indicated by AB (Alberta) or BC (British Columbia).

${ }^{3}$ First-calf heifers from B.C. with an unknown history of exposure to TMV.

47 and 72 cows in control and supplement groups respectively.

cows from B.C. In each year, in vitro rates of detoxification were determined after cattle were on pasture $\mathrm{C}$ for 2 weeks (Date $1)$, after they were in pastures $A$ and $B$ for 2 weeks (Date 2) and at the end (Date 3).

Grazing trials at Sixtyone Creek were not conducted in 1997 to permit the forage on the range pastures to recover from grazing pressure. After 5 years of grazing (1992 - 1996), the TMV biomass had been substantially reduced. During that period, the average stocking rate was $3.5 \mathrm{ha} / \mathrm{AUM}$ which is heavier than the recommended rate of $4 \mathrm{ha}$ /AUM for that area. The increased grazing pressure promoted the utilization of TMV. Subsequently, the average stocking rate was set at 4.1 ha/AUM

\section{8, 1999, and 2000 Grazing Trials}

Prior exposure to timber milkvetch (TMV) appears to be a critical factor in subsequent resistance to TMV. It was not known whether this exposure was critical at the suckling calf stage or at the yearling heifer stage. The 1998 season was the first phase of a 3 year program to assess the susceptibility of female cattle to TMV poisoning between the state of puberty and maturity.

Thirty heifer calves were purchased in 1997. Half were from the prairie region of Alberta, where TMV is not available, and half were from the Cariboo region of B.C., where TMV is abundant. They were overwintered and bred in Kamloops before the 1998 TMV grazing season when they were divided into 2 groups of 15 . The control group contained 8 heifers from B.C. and 7 from Alberta. The supplement group contained 8 heifers from Alberta and 7 from B.C. The supplement group was given protein blocks free choice and the other served as a control.
The 1999 season was the second phase of the 3-year program that would test the effect of age on the susceptibility of lactating cows to TMV. Only 24 first-calf heifers were available for TMV range trials in 1999. Due to calving problems, it was not possible to assign the same animals to each supplement group in 1999 but they were kept in the same groups in 1999 and 2000. Each group of 12 consisted of 5 cow-calf pairs from Alberta and 7 from B.C. One group was given protein supplements and the other served as a control.

The third phase was conducted in the summer of 2000 when the susceptibility of these same heifers, now as second-calf heifers, was assessed. In the 2000 trial, the control group consisted of 5 cow-calf pairs from B.C. and 5 from Alberta. The treated group had 6 cow-calf pairs from B.C. and 5 from Alberta.

\section{Statistical Analysis}

Data on the incidence of poisoning in cattle were analyzed using logistic regression (Hosmer and Lemeshow 1989). A binary variable $\mathrm{Y}$ was created for each animal, and was assigned the value $\mathrm{Y}=1$ if the animal showed symptoms of poisoning and 0 if not. Logistic regression estimates the relationship $P(Y=1)=$ $1 /\left(1+\exp \left(-\left(a+b^{*} X\right)\right)\right)$ where $P(Y=1)$ is the probability that an animal showed symptoms of poisoning, $a$ is a constant estimated from the data, $\mathrm{X}$ is an independent treatment variable, and $b$ is the estimate of slope with respect to the independent variable. The independent treatment variable $\mathrm{X}$ was a binary variable to allow estimating the magnitude of the response across 2 groups. The variable used depended on the comparison of interest. The risk of poisoning for a group of cattle was estimated as $\sum Y / n$ where $\sum Y=$ the number of animals that exhibited symptoms of poisoning and $n=$ the total number of animals in the group. The odds of an animal in a group exhibiting symptoms of poisoning were estimated as $\sum Y /(n$ $\left.\sum Y\right)$ and describe how likely the symptoms of poisoning occurred in a group. Since the variable $\mathrm{X}$ was always a binary variable, the odds ratio for the 2 groups was estimated directly from the logistic regression equation as $\exp (b)$, and describes how much more likely poisoning occurred in 1 group compared with another. All logistic regressions were conducted using SPSS (SPSS Inc. 2000).

The effect of supplementation on the incidence of poisoning in cattle was estimated by logistic regression using data from all trials. The variable $\mathrm{X}$ was assigned the value 0 for control animals (no supplementation) and 1 for supplemented animals, and logistic regression used to determine if the incidence of poisoning was influenced by supplementation.

The effect of animal age on the incidence of poisoning in cattle was estimated by logistic regression using data for the control (unsupplemented animals) from the 1993 and 1998-2000 trials. Supplemented animals were not used in this analysis since the incidence of poisoning was low in all trials. The variable $\mathrm{X}$ was assigned the value 1 if the animals were $2-3$ years old, and 0 if the animals were either 1 year old or 4+ years old, and logistic regression used to determine the significance of the effect.

The effect of animal origin on the incidence of poisoning was determined using data from 1995-1996 and 1998-2000 since these trials all contained animals from both locations. Supplemented animals were not used in this analysis. The variable $X$ was assigned the value 1 if the animals came from Alberta and 0 if they 
came from B.C., and logistic regression used to compare the incidence of poisoning among cattle originating from Alberta and B.C.

In vitro detoxification rates from 1995 to 2000 were analysed using repeated measures ANOVA (PROC GLM, SAS 1995). During 1995 to 2000 , each experiment was a $2 \times 2$ factorial with 2 treatments (with or without protein supplements) and 2 origins of livestock (Alberta or B.C.) with a treatment $\mathrm{x}$ origin interaction (SAS 1995), which was not statistically significant. These were considered between-subject effects and sampling dates within each year were considered within-subject effects since measurements were made on the same animals over time. Data were analysed separately for each year since different animals were used in 1995, 1996 and 1998-2000. Also, animal numbers varied from 1998-2000, so these years were analysed separately. A significance level of 0.05 was used throughout the study.

\section{Results}

\section{Clinical Signs}

In early signs of timber milkvetch (TMV) poisoning, we observed that animals may be gaunt or slightly bloated with some respiratory abnormalities and general lethargy. These signs invariably progress to acute poisoning with continued exposure and animals with early or subacute symptoms were usually removed from the study. Acute signs of TMV poisoning were manifested as incontinence, loss of hindquarter co-ordination, excessive salivation, reluctance to move, a strong tendency to become recumbent and general untractability. In chronic poisoning, there is permanent damage manifested as unthriftiness, diarrhea, loss of stamina, and clicky heels (James et al. 1980, Majak et al. 1981). Signs of chronic poisoning were frequently delayed and were often manifested when cattle were suddenly exerted and forced to travel. Affected animals will usually lag behind the rest of the herd. This was often seen after the completion of the grazing trial when cattle were moved to their home range. In this study, an incident of TMV poisoning was classified as the occurrence of clinical signs of early, acute, or chronic poisoning in one animal and on one or more days of the season.

\section{Effect of Supplements}

The incidence of poisoning in control animals was $35 \%(25 / 71)$ and was $3 \%$ $(2 / 72)$ in supplemented animals (Table 2$)$. The odds of poisoning were 0.54 ( 25 poisoned: 46 not poisoned) and 0.03 (2 poisoned: 70 not poisoned) in the control and supplemented groups respectively. Logistic regression indicated that supplementation significantly reduced the odds of poisoning $\left(\chi^{2}=28.2 ; \mathrm{df}=1 ; \mathrm{P}<\right.$ $0.0001)$. The parameter estimates $( \pm \mathrm{SE})$ were $a=-0.610( \pm 0.248)$ and $b=-2.945$ $( \pm 0.759)$. The estimate of $b$ was significant $(\mathrm{t}=15.1 ; \mathrm{df}=1 ; \mathrm{P}<0.0001)$. The odds of poisoning were $19.0(95 \% \mathrm{CI}=$ $4.3,84.2$ ) times greater in the unsupplemented groups compared with the supplemented groups.

Two-year-old heifers with an unknown history of exposure to timber milkvetch (TMV) were used for the first time in the 1993 TMV grazing trial. Three of these 2year olds that were part of the unsupplemented group showed signs of TMV poisoning (Table 2) and were removed from the trial due to acute or early signs of TMV poisoning. In 1995, 3 of the 6 naive heifers in the control group suffered from acute TMV poisoning, and were removed from the trial 2 weeks before its conclusion (Table 2). In 1996, there was a low incidence of TMV poisoning. Only 1 Alberta heifer in the control group was prematurely withdrawn from the trial. The low incidence of poisoning in 1996 was attributed to the overgrazed condition of the TMV range. Grazing at the Sixtyone Creek pastures was discontinued in 1997 to permit recovery of TMV and other forage.

In summary, the control group yielded 25 cases of TMV poisoning during the 6year study, compared with 2 for the supplement group. The supplement increased rates of TMV detoxification $(>50 \%)$ in only 1 of the 5 years of testing (Table 3 ). The innate capacity to transfer rumen microbial activity between cattle in close proximity and the natural enrichment of rumen microbial populations (Anderson et al. 1998) might elevate rates of detoxification regardless of treatment.

\section{Effect of Age}

Age classes in the control groups were compared across years because it was not feasible to have each age class in each year and the experimental site could not accommodate more cattle. Data for 1993 and 1998-2000 were combined since the number of animals in any one year were low. The incidence of poisoning was $5 \%$ (1/20) for 1 year-old (1998) and 4+ yearold animals (1993) compared with 53\% (14/27) for 2-3 year-old animals in 1993, 1999, and 2000 (Table 2). The odds of poisoning were $0.05(1 / 19)$ and 1.08 $(14 / 13)$ in the respective groups. Logistic regression indicated that the effect of age was significant $\left(\chi^{2}=13.5 ; \mathrm{df}=1 ; \mathrm{P}<\right.$ $0.0001)$ and the parameter estimates $( \pm$ SE) were $a=-2.943( \pm 1.025)$ and $b=$ $3.017( \pm 1.095)$. The estimate of $b$ was significant $(\mathrm{t}=7.6 ; \mathrm{df}=1 ; \mathrm{P}<0.0001)$. The odds of poisoning were 20.4 (95\% CI $=2.4,174.8$ ) times greater for $2-3$ year old animals compared with the other age classes. Older cows were also used in TMV studies during 1990 to 1992 without showing ill effects (Majak et al. 1996).

There was no incidence of timber milkvetch (TMV) poisoning among yearling heifers in 1998 (Table 2). This concurs with local producers' experience that non-lactating females are unlikely to be susceptible to TMV. In 1999, a supplemented Alberta 2-year old first-calf heifer showed early signs of TMV poisoning and she was removed from the trial. This heifer was part of the previous year's group that was not given access to protein blocks and it is possible that she was unfamiliar with the supplement. Toward the end of the trial, a 2-year old B.C. heifer in the control group showed acute signs of TMV poisoning and remained on the range with her calf due to respiratory problems and her inability to trail. Four other 2-year old heifers from Alberta in the control group also showed early signs of poisoning (Table 2).

The 2000 season concluded a 3-year investigation to assess the susceptibility of young female cattle to poisoning by TMV. There were no acute cases of TMV poisoning in 3-year old cows at Sixtyone Creek in 2000 (Table 2). However, on return to the home range at Pass Lake, 3 control cows ( 2 from B.C. and 1 from Alberta) developed the "clicky heel" syndrome associated with chronic TMV poisoning. This clinical sign did not appear until cattle were moved some considerable distance and the condition persisted into winter. As well, 2 additional cows from the control group showed the same chronic signs in the fall (Table 2). It should be noted that none of these cows showed acute signs at Sixtyone Creek in 2000 or in the previous year. 
Table 3. Average rates of NPOH detoxification by ruminal bacteria in cattle grazing TMV and treated with or without protein supplements.

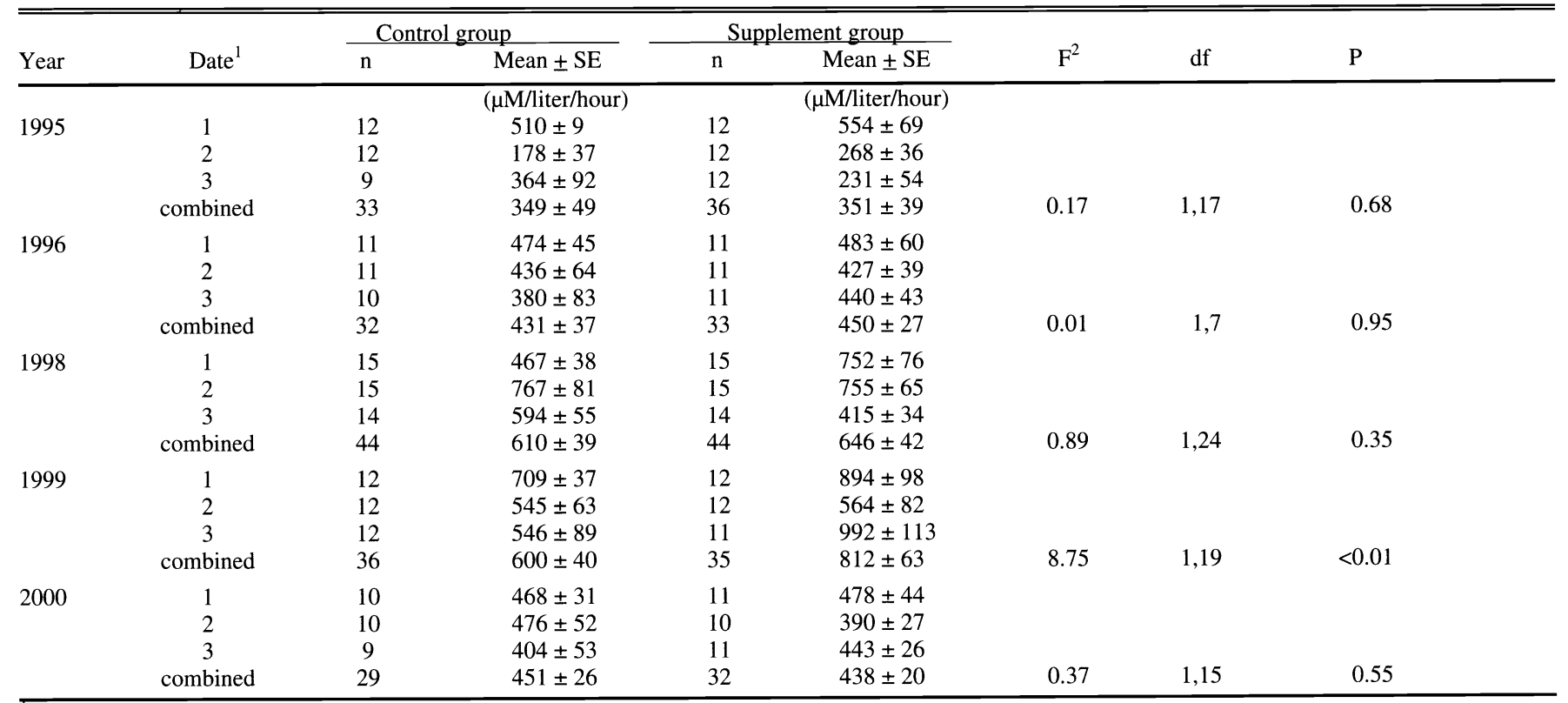

Date 1 determination in pasture $\mathrm{C}$; dates 2 and 3 in pastures $\mathrm{A}$ and $\mathrm{B}$.

${ }^{2}$ F-test for the effects of supplement.

\section{Effect of Origin}

The effect of origin was compared across years in the control group from 1995 to 2000 (Table 2). The incidence of poisoning was $25 \%(8 / 32)$ for indigenous cattle originating in B.C. and $45 \%$ (13/29) for naive cattle originating from Alberta. The odds of poisoning were $0.33(8 / 24)$ and $0.81(13 / 16)$ respectively for cattle originating from B. C. and Alberta. Logistic regression indicated that the effect of origin was marginally significant $\left(\chi^{2}=2.7 ; \mathrm{df}=1 ; \mathrm{P}=0.10\right)$ and the parameter estimates $( \pm \mathrm{SE})$ were $a=-1.099( \pm$ $0.408)$ and $b=0.891( \pm 0.553)$. The estimate of $b$ was also marginally significant $(t=2.6 ; \mathrm{df}=1 ; \mathrm{P}=0.10)$. The odds of poisoning were $2.4(95 \% \mathrm{CI}=0.8,7.2)$ times greater for cattle originating from Alberta compared to those originating from B. C. The $95 \%$ confidence interval overlapped with 1 , so these results can only be taken as suggestive of an effect of origin.

\section{In vitro Detoxification Rates}

The average daily intake of the molasses blocks was 1.4 and $1.8 \mathrm{~kg}$ per cow-calf pair in 1995 and 1996 respectively. There was no rate difference between supplement and control groups in 1995 and 1996 (Table 3). The average daily intake of the molasses blocks was $0.6 \mathrm{~kg}$ per head in 1998 and 1.1 and $1.6 \mathrm{~kg}$ per cow-calf pair in 1999 and 2000. In 1998, in vitro rates of detoxification were initially determined in spring when the cattle were on tame grass pastures before being transported to forest range. These rates were relatively low $(148 \mu \mathrm{M} /$ liter/hour \pm 16 on May 12$)$ but they escalated dramatically after 2 weeks on pasture $\mathrm{C}$. The rate for the supplement group increased to $752 \mu \mathrm{M} /$ liter/hour (SE $=76)$ and to $467 \mu \mathrm{M} /$ liter/hour $(\mathrm{SE}=38)$ for the unsupplemented group (Table 3). A significant date*treatment term $(\mathrm{F}=10.2$; $\mathrm{df}=1,24 ; \mathrm{P}=0.0002$ ) indicated that changes in detoxification rates across time were not consistent among groups. Detoxification rates were highest on date 1 for the supplement group, but the control group was highest on date 3 (Table 3 ). These results show that the rumen microbe populations can shift to effectively detoxify timber milkvetch (TMV), and thus permit a high level of tolerance in cattle grazing TMV. The rates of detoxification were higher for the supplement group compared with the control group in 1999 (Table 3) but no difference was observed in 2000 .

The naive Alberta yearlings had lower $(\mathrm{P}<0.05)$ initial rates of TMV detoxification (Table 4) during 1998. During the 1999 trial, ruminal rates of detoxification were consistently lower $(\mathrm{P}<0.05)$ for the heifers from Alberta than for those from B.C. (Table 4). This was most apparent towards the end of the trial when the average rates differed by $300 \mu \mathrm{M} /$ liter/hour. The supplement also had the largest impact at that time when, on average, the supplement group exceeded the control group by $400 \mu \mathrm{M} /$ liter/hour (Table 3 ). There was no difference in rates in 2000 . The lower rate of TMV detoxification for yearling heifers not previously exposed to TMV suggests that, to acquire resistance to TMV, exposure to TMV at the suckling calf stage is critical. Native cattle yielded higher rates of TMV detoxification (> $25 \%$ ) on only two of the five years of testing (Table 4). The innate capacity to transfer rumen microbial activity between cattle in close proximity and the natural enrichment of rumen microbial populations might elevate rates of detoxification over time regardless of origin.

\section{Discussion}

The 1998-2000 study at Sixtyone Creek confirmed that first-calf heifers are most susceptible to timber milkvetch (TMV) poisoning and they can show acute signs, second-calf heifers can develop delayed, chronic symptoms and yearling heifers are least susceptible (Table 2). To acquire resistance to TMV, exposure to TMV at the suckling calf stage is critical. Previous exposure to TMV can have a significant impact on subsequent resistance to TMV. As well, we have confirmed that protein supplements provide adequate protection from TMV, especially for native cattle of B.C. that are adapted to TMV. Clinical 
Table 4. Average rates of NPOH detoxification by ruminal bacteria in cattle grazing TMV and originating from either British Columbia or Alberta.

\begin{tabular}{|c|c|c|c|c|c|c|c|c|}
\hline \multirow[b]{2}{*}{ Year } & \multirow[b]{2}{*}{ Date $^{1}$} & \multicolumn{2}{|c|}{ British Columbia } & \multicolumn{2}{|c|}{ Alberta } & \multirow[b]{2}{*}{$\mathrm{F}^{2}$} & \multirow[b]{2}{*}{$\mathrm{df}$} & \multirow[b]{2}{*}{$\mathrm{P}$} \\
\hline & & $\mathrm{n}$ & Mean $\pm S E$ & $\mathrm{n}$ & Mean $\pm S E$ & & & \\
\hline 1995 & $\begin{array}{c}1 \\
2 \\
3 \\
\text { combined }\end{array}$ & $\begin{array}{l}12 \\
12 \\
12 \\
36\end{array}$ & $\begin{array}{c}(\mu \mathrm{M} / \text { liter/hour }) \\
460 \pm 69 \\
254 \pm 42 \\
308 \pm 76 \\
341 \pm 39\end{array}$ & $\begin{array}{c}12 \\
12 \\
9 \\
33\end{array}$ & $\begin{array}{c}(\mu \mathrm{M} / \text { liter/hour }) \\
603 \pm 85 \\
192 \pm 34 \\
261 \pm 65 \\
360 \pm 49\end{array}$ & 0.46 & 1,17 & 0.50 \\
\hline 1996 & $\begin{array}{c}1 \\
2 \\
3 \\
\text { combined }\end{array}$ & $\begin{array}{l}12 \\
12 \\
12 \\
36\end{array}$ & $\begin{array}{l}460 \pm 55 \\
473 \pm 48 \\
377 \pm 48 \\
437 \pm 29\end{array}$ & $\begin{array}{c}10 \\
10 \\
9 \\
29\end{array}$ & $\begin{array}{l}500 \pm 48 \\
382 \pm 54 \\
457 \pm 84 \\
446 \pm 36\end{array}$ & 0.18 & 1,17 & 0.68 \\
\hline 1998 & $\begin{array}{c}1 \\
2 \\
3 \\
\text { combined }\end{array}$ & $\begin{array}{l}15 \\
15 \\
14 \\
44\end{array}$ & $\begin{array}{l}699 \pm 71 \\
851 \pm 85 \\
557 \pm 43 \\
706 \pm 43\end{array}$ & $\begin{array}{l}15 \\
15 \\
14 \\
44\end{array}$ & $\begin{array}{l}519 \pm 62 \\
671 \pm 49 \\
453 \pm 55 \\
550 \pm 35\end{array}$ & 7.40 & 1,24 & $<0.02$ \\
\hline 1999 & $\begin{array}{c}1 \\
2 \\
3 \\
\text { combined }\end{array}$ & $\begin{array}{l}14 \\
14 \\
14 \\
42\end{array}$ & $\begin{array}{l}885 \pm 82 \\
658 \pm 61 \\
883 \pm 119 \\
809 \pm 53\end{array}$ & $\begin{array}{c}10 \\
10 \\
9 \\
29\end{array}$ & $\begin{array}{l}685 \pm 47 \\
409 \pm 65 \\
567 \pm 81 \\
553 \pm 42\end{array}$ & 15.01 & 1,19 & $<0.01$ \\
\hline 2000 & $\begin{array}{c}1 \\
2 \\
3 \\
\text { combined }\end{array}$ & $\begin{array}{l}11 \\
11 \\
11 \\
33\end{array}$ & $\begin{array}{l}478 \pm 43 \\
483 \pm 36 \\
418 \pm 49 \\
460 \pm 25\end{array}$ & $\begin{array}{c}10 \\
9 \\
9 \\
28\end{array}$ & $\begin{array}{l}467 \pm 33 \\
371 \pm 45 \\
434 \pm 15 \\
426 \pm 20\end{array}$ & 0.87 & 1,15 & 0.37 \\
\hline
\end{tabular}

${ }_{2}$ Date 1 determination in pasture $\mathrm{C}$; dates 2 and 3 in pastures $\mathrm{A}$ and $\mathrm{B}$.

${ }^{2}$ F-test for the effects of supplement.

signs of TMV poisoning were never observed in calves.

Overall, the results indicate that supplementation and animal age were the most important factors determining the likelihood of poisoning, and that geographic origin had a marginal influence. There was considerable variability in detoxification rates. Individual differences indicated that there could be a tenfold variation in rates of TMV detoxification among cattle regardless of treatment. In 1995 for example, the range of values for the control group was 10-620 ( $\mu \mathrm{M} /$ /iter/hour) and for the supplement group it was 81-425. In 1996, the values ranged from 193-740 and 226-759 for the 2 groups, respectively. Clearly, some cattle had acquired a resistance to TMV poisoning as evidenced by their enhanced rates of TMV detoxification regardless of treatment. Changes from year to year may reflect differences among animals or in forage quality. The absence of treatment differences during 1995 and 1996 (Table 3) might be attributed to the adaptation of the control groups to TMV and the natural in vivo enrichment of detoxifying bacteria (Anderson et al. 1998). As well, it is documented that a transfer of rumen microbial activity can occur between treated and control groups by contact or through close proximity (Cheng et al. 1985). This type of contact would have been possible during the ini- tial grazing interval on pasture $\mathrm{C}$ when the cattle were in adjacent fields. The animals also shared a common squeeze chute when sampled. It should also be noted that in earlier studies (Majak 1992) control groups on domesticated feeds showed much lower rates of detoxification (60-262).

The limitations of the stomach pump sampling technique should be noted. Unlike obtaining whole rumen contents via cannula, the tube method yields fluid samples with a variable proportion of saliva. Rumen bacteria are primarily associated with the particulate phase of rumen digesta (McAllister et al. 1994). This phase is obtained in limited quantities by the tube method. Also, the typical volume of the composite sample via cannula ( 500 $\mathrm{ml}$ ) is much larger and more representative of rumen contents than the smaller tube sample $(50 \mathrm{ml})$. When duplicate samples $(n=74)$ were obtained by the tube method, the agreement between sample rates was acceptable. The average difference was $12.5 \%$ with a $95 \%$ confidence interval of 3.2 to $23 \%$. To avoid further trauma, it was not feasible to obtain rumen samples from affected animals due to their poor and unstable condition.

Rates of detoxification were not detectably affected by protein supplementation in 2000 (Table 3) and effect of origin was less pronounced in 2000 than in
1999 (Table 4). The latter suggests that the effect of origin on rates of detoxification declines in second-calf heifers due to previous exposure to timber milkvetch (TMV). Higher rates were evident for B.C. cattle during 1998-2000 but not during 1995-96 (Table 4). Cattle from B.C. were purchased from the Cariboo region in 1998 where TMV is a major component of their diet (Majak et al. 1996). In contrast, B.C. cattle in 1995 and 1996 were purchased from the greater Kamloops region where TMV is a minor or occasional component in the Douglas Fir forest.

It is also possible that tolerance to TMV could be mediated by hepatic mechanisms. Amino acid conjugation of natural products by hepatic enzymes is known to occur (Scheline 1991) and amino acid conjugates of 3-nitropropionic acid (NPA) have been detected in nature (Majak et al. 1998). The relative rates of hepatic bioactivation (oxidation of NPOH to NPA) and detoxification (reduction or conjugation) might also be a factor in the differential toxicity of NPOH to cattle.

\section{Management Implications}

Incidents of early, acute and chronic timber milkvetch (TMV) poisoning were documented using 143 cows in a 6-year study at a lodgepole pine forest site in 
B.C. Lactating first-calf heifers were most susceptible to TMV and they showed acute signs of poisoning. Second calf heifers showed delayed chronic signs especially during exertion. Older cows and yearling heifers were the least susceptible. Heifers that were purchased in Alberta and not previously exposed to TMV were more prone to TMV poisoning than cattle that were native to B.C. Protein supplements provided adequate protection from TMV regardless of age or prior history.

\section{Literature Cited}

Alston, T.A., L. Mela, and H.J. Bright. 1977. 3-Nitropropionate, the toxic substance of Indigofera, is a suicide inactivator of succinate dehydrogenase. Proc. Natl. Acad. Sci. USA 74:3767-3771.

Anderson, R.C., M.A. Rasmussen, and M.J. Allison. 1993. Metabolism of the plant toxins nitropropionic acid and nitropropanol by ruminal microorganisms. Appl. Environ. Microbiol. 59:3056-3061.

Anderson, R.C., W. Majak, Rasmussen, M.A., and M.J. Allison. 1998. Detoxification potential of a new species of ruminal bacteria that metabolize nitrate and naturally occurring nitrotoxins, p. 154-158. In: T. Garland and A.C. Barr (eds.), Toxic plants and other natural toxicants. CAB International, New York, N.Y.

Anderson, R.C., M.A. Rasmussen, A.A. DiSpirito, and M.J. Allison. 1997. Characteristics of a nitropropanol-metabolizing bacterium isolated from the rumen. Can. J. Microbiol. 43:617--624.
Anderson, R.C., M.A. Rasmussen, N.S. Jensen, and M.J. Allison. 2000. Denitrobacterium detoxificans gen. nov., sp. nov., a ruminal bacterium that respires on nitrocompounds. Intern. J. Syst. Evol. Microbiol. 50:633-638.

Cheng, K.-J., R.C. Phillippe, G.C. Kozub, W. Majak, and J.W. Costerton. 1985. Induction of nitrate and nitrite metabolism in bovine rumen fluid and the transfer of this capacity to untreated animals. Can. J. Anim. Sci. 65:647-652.

Coles, C.J., D.E. Edmondson, and T.P. Singer. 1979. Inactivation of succinate dehydrogenase by 3-nitropropionate. J. Biol. Chem. 254:5161-5167.

Hosmer, D.W. and S. Lemeshow. 1989. Applied logistic regression. John Wiley \& Sons, New York.

James, L.F., W.J. Hartley, M.C. Williams, and K.R. Van Kampen. 1980. Field and experimental studies in cattle and sheep poisoned by nitro-bearing Astragalus or their toxins. Am. J. Vet. Res. 41:377-382.

Majak, W. 1992. Further enhancement of 3nitropropanol detoxification by ruminal bacteria in cattle. Can. J. Anim. Sci. 72:863-870.

Majak, W. and M.A. Pass. 1989. Aliphatic nitrocompounds, p. 144-159. In: P.R. Cheeke (ed.), Toxicants of Plant Origin, Vol. II Glycosides. CRC Press Inc., Boca Raton, Fla.

Majak, W. and B.M. Wikeem. 1986. Miserotoxin levels in fertilized Astragulus miser var serotinus. J. Range Manage. 39:130-131.

Majak, W., C. Hunter, and L. Stroesser. 1998. Tolerance in cattle to timber milkvetch (Astragalus miser var. serotinus) due to changes in rumen microbial populations, $\mathrm{p}$. 239-242. In: T. Garland and A.C. Barr (eds), Toxic plants and other natural toxicants. CAB International, New York, N.Y.
Majak, W., D.L. Johnson, and M.H. Benn. 1998. Detoxification of 3-nitropropionic acid and karakin by melanopline grasshoppers. Phytochem.. 49:419-422.

Majak, W., T. Udenberg, R.E. McDiarmid, and $H$. Douwes. 1981. Toxicity and metabolic effects of intravenously administered 3nitropropanol in cattle. Can. J. Anim. Sci. 61:639-647.

Majak, W., L. Stroesser, J.W. Hall, D.A. Quinton, and H.E. Douwes. 1996. Seasonal grazing of Columbia milkvetch by cattle on rangelands in British Columbia. J. Range Manage. 49:223-227.

Maricle, B., J. Tobey, W. Majak, and J.W. Hall. 1996. Evaluation of clinicopathological parameters in cattle grazing timber milkvetch. Can. Vet. J. 37:153-156.

McAllister, T.A., H.D. Bae, G.A .Jones, and K.-J. Cheng. 1994. Microbial attachment and feed digestion in the rumen. J. Anim. Sci. 72:3004-3018.

SAS Institute. 1995. SAS User's Guide Release 6.12. SAS Institute Inc., Cary, N.C.

Scheline, R.R. 1991. Handbook of mammalian metabolism of plant compounds. CRC Press, Boca Raton, Fla.

SPSS Inc. 2000. SPSS 10.0. Regression models. SPSS Inc., Chicago, Ill.

Wikeem, B.M., A. McLean, A. Bawtree, and D. Quinton. 1993. An overview of the forage resource and beef production on Crown land in British Columbia. Can. J. Anim. Sci. 73:779-794. 